\title{
Nobelpris for mitotisk klokke
}

Nobelprisen i fysiologi eller medisin for 2009 er tildelt Elizabeth H. Blackburn, Carol W. Greider og Jack W. Szostak for «oppdagelsen av hvordan kromosomene er beskyttet av telomerer og enzymet telomerase». Allerede i 1930-årene la cytogentikere merke til at kromosomer tenderte til å hefte seg sammen og nedbrytes hvis endestykkene manglet. Hermann Muller (nobelpris 1946) og Barbara McClintock (nobelpris 1983) konkluderte derfor at kromosomendene spiller en avgjørende rolle for kromosomets stabilitet (1). Muller introduserte betegnelsen telomer for endestykket, fra gresk «telos» (ende) og «meros» (del), men ingen kunne forklare hvordan telomerene fungerte stabiliserende. I 60-årene ble man oppmerksom på et annet utfordrende spørsmål: Når det dobbeltrådige DNA-molekylet kopieres av DNA-polymerase, skulle enden av den ene tråden ikke bli kopiert. Hvordan kan likevel cellepopulasjoner regenerere uten at kromosomene blir kortere? Årets prisvinnere har forklart både hvordan kromosomene beskyttes mot degradering og hvordan vårt arvemateriale kopieres komplett. Deres oppdagelser har videre fått stor betydning for vår kunnskap om mitosekontroll, stamceller og kreftutvikling og synes å åpne for nye terapeutiske strategier.

Blackburn og Szostak møttes på en konferanse i 1980. Gjennom genstudier på Tetrahymena, en encellet organsime, hadde Blacburn identifisert en kort DNA-sekvens som ble repetert mange ganger på enden av hvert kromosom. Szostak fattet interesse for denne sekvensen, fordi han hadde oppdaget at lineære DNA-molekyler («minikromosomer») raskt ble degradert etter overføring til gjærceller. De to bestemte seg for å koble telomersekvensen fra Tetrahymena på minikromosomet og overføre det til gjærcellene. Effekten var oppsiktsvekkende: Minikromosomet ble beskyttet fra degradering (2). Det har senere vist seg at telomerprinsippet for kromosomstabilisering representerer et fundamentalt trekk ved eukaryote organismer (dyr, planter, sopp, protozoer).

Blackburn og hennes stipendiat Greider besluttet så å undersøke hvordan telomerer blir dannet. Første juledag 1984 fanget de opp aktivitet fra et telomerdannende enzym som fikk navnet telomerase (3). Enzymet viste seg å representere et kompleks av RNA og ulike proteiner (4). RNA-komponenten fungerer som templat («oppskrift») for kompleksets katalytiske subenhet, telomerase reverstranskriptase (TERT), som syntetiserer telomerene. Med dette hadde man forklart hvordan genomet kan kopieres komplett.

Betydningen av denne oppdagelsen fremkom da det viste seg at telomerase uttrykkes av stamceller, men ikke av vanlige somatiske celler. Dette innebærer at stamceller kan fylle på med nye telomerer for hver mitose, mens somatiske celler bare kan gjennomgå et begrenset antall delinger. Telomerene fungerer dermed som en «mitotisk klokke» og representerer et effektivt hinder mot ukontrollert proliferasjon. Tumorceller nullstiller sin klokke ved å begynne å uttykke telomerase. Betydningen av dette trinnet i onkogenesen kan illustreres ved at man har påvist telomerase $\mathrm{i}$ alle undersøkte kreftformer. Videre er telomerase høyt uttrykt i såkalte kreftstamceller. Dette er en subgruppe blant svulstens celler som har evnen til endeløs celledeling og antas å representere den reelle trussel mot pasienten.

Det viser seg at telomeravvik er assosiert med en rekke sykdommer, særlig tilstander med utilstrekkelig celleregenerering eller mangel- full vekstkontroll (1). Individer med korte telomerregioner har økt risiko for skrumplever og lungefibrose. Korte telomerer gir også $ø$ kt risiko for tykktarmskreft hos pasienter med ulcerøs kolitt. Videre knyttes mutasjoner i telomerasegener til en lang rekke arvelige tilstander, primært sykdommer i vev med høy regenerasjonshastighet (beinmarg, hud, lunge, tarm). Telomeravvik synes dernest å spille en sentral patogenetisk rolle i progeroidsyndromer, dvs. tilstander karakterisert ved akselerert aldring. Dette gjelder også syndromer primært forårsaket av mutasjoner i andre gener, slik som Fanconis anemi og ataxia-teleangiectasia, hvor abnormaliteter i telomerreplikasjonen kan være avgjørende for sykdomsmanifestasjonen.

Oppdagelsen av telomeraseenzymet har gitt opphav til en rekke strategier for nye terapier. Induksjon av telomeraseaktivitet benyttes alt in vitro for å forlenge cellers livssyklus og forsøkes også etablert for klinisk bruk, i første omgang for å motvirke sykdommer knyttet til utilstrekkelig cellegenerering/stamcellefunksjon. Videre tenkes telomeraseinduksjon anvendt for å fremdyrke vev og celler til transplantasjon. Innen kreftterapi fremstår telomerase som et særlig attraktivt angrepspunkt, ettersom enzymet uttrykkes universelt i alle kreftformer og av tumorceller med stamcelleegenskaper. Det forsøkes bl.a. utviklet småmolekylære enzymhemmere, agenser som blokkerer telomeraseuttrykk og vaksiner som skal stimulere til immunangrep mot telomerasepositive celler (5). Kliniske studier pågår i hovedsak med vaksiner (6), og norske forskere har her vært tidlig ute. En telomerasebasert kreftvaksine, utviklet ved Oslo universitetssykehus (Radiumhospitalet og Ullevål), er evaluert i flere fase 1-/ fase 2-studier og brakt inn i fase 3-utprøvning ved bukspyttkjertelkreft. Det må likevel understrekes at det er for tidlig å si om slike vaksiner vil vise seg klinisk effektive.

Historien om årets nobelpris er altså gammel, men under stadig utvikling. Den er et godt eksempel på hvordan forskning på grunnleggende biologi kan gi opphav til nye forskningsfelter med spennende anvendelsesmuligheter. Prisvinnerne har vist stor interesse for at deres oppdagelser skal utnyttes terapeutisk. Når basale nyvinninger skal overføres til medisinsk nytte, er som kjent fallhøyden proporsjonal med det antatte potensialet. Mye taler likevel for at årets nobelpris ikke blir den siste som tilfaller telomerrelatert forskning.

\section{Jon Amund Kyte \\ jon.amund.kyte@rr-research.no}

Jon Amund Kyte (f. 1972) er dr.med. innen cancerimmunterapi og lege ved Oslo universitetssykehus, Radiumhospitalet. I forskningssammenheng arbeider han med utvikling av kreftvaksiner, bl.a. vaksiner basert på telomeraseantigener.

\section{Oppgitte interessekonflikter: Ingen}

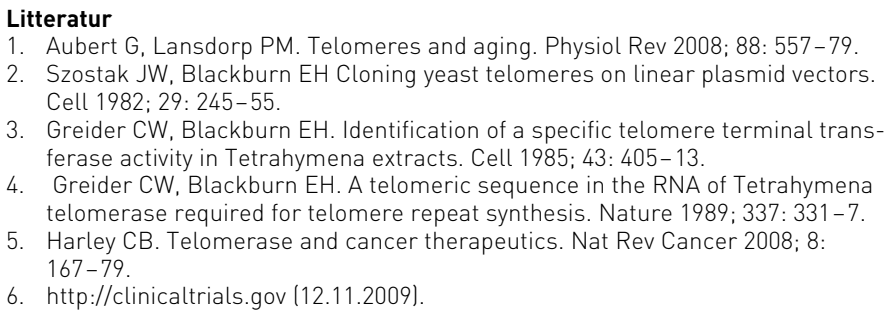

